are produced as a result of the interaction of two metabolic systems, host and parasite, and which inhibit the growth of micro-organisms pathogenic to plants"'3. In this sense, citric acid, although present in healthy fruit at a non-toxic concentration, might be regarded as a phytoalexin since it reaches toxic levels through the activity of the invading pathogen. The ethyl acetate soluble antibiotic remaining after the removal of acids could likewise be considered as a phytoalexin.

Agricultural Research Council Plant

D. M. SPEncer

G. A. Carter

Growth Substance and Systemic Fungicide Unit, Wye College, Near Ashford, Kent.

${ }^{1}$ Cruickshank, I. A. M., Ann. Rev. Phytopathol., 1, 351 (1963).

'Müller, K. O., and Börger, H., Arb. Biol. Reichsanstalt Land-u Forstuirtsch,

${ }^{3}$ Müller, K. O., Phytopath. Z., 27, 237 (1956).

\section{Thermal and Translocated Induction of Endophytic Mycelium in two Powdery Mildews}

ENDOPHYTIC mycelium of various biotypes of Erysiphe graminis was demonstrated by Salmon ${ }^{1}$ in cereal leaves which had boen mechanically damaged or heated to $50^{\circ} \mathrm{C}$ for short periods immediately prior to inoculation. Schnathorst $^{2}$ obtained endophytic mycelium of $E$. cichoracearum in lettuce leaves by stripping ono epidermis and inoculating the exposed mesophyll. Yarwood ${ }^{3}$ found that heat both predisposed cucumber cotyledons to infection by Sphaerotheca fuliginea ${ }^{4}$ and made them less responsive to subsequent heat therapy. Yarwood ${ }^{5}$ also demonstrated that heat treatment, abrasion or infection by Uroymces phaseoli rendered Phaseolus vulgaris susceptible to infection by $S$. fuliginea, by which it is not normally attacked, and Yarwood et al. ${ }^{6}$ and Nienhaus and Yarwood ${ }^{7}$ showed that some effects of heating one leaf of an opposite pair could bo transmitted to the other, for example, increased susceptibility of bean and cowpea to a strain of tobacco mosaic virus.

Continuing this type of work with S. fuliginea, it was observed that when one of a pair of cucumber cotyledons, about 14 days old, was heated in water at $45^{\circ}, 50^{\circ}$ or $55^{\circ} \mathrm{C}$ for periods of $\frac{1}{2}-120 \mathrm{sec}$, eith $\mathrm{r} 12 \mathrm{~h}$ before inoculation of the upper surface of both cotyledons, or up to 7 days after inoculation, the mycelium became endophytic in both cotyledons. Similar results were obtained in experiments made with the first truo leaves of sunflower seedlings inoculated with $E$. cichoracearum.

Thermal induction of endophytic mycelium, first noted by Salmon ${ }^{1}$, was confirmed in barley seedlings inoculated with the barley isolate of $E$. graminis, although here no translocated effect was observed.

In all cases, an intercellular mycelium was formed, and typical haustoria were formed in the mosophyll and palisado colls, in the parenchyma of the vascular bundles and in the opposite uninoculated epidermis. Conidiophores and conidia were formed externally on this and on the inoculated epidermis and also occasionally in the intercellular spaces, variously orientated to the leaf surface.

In sunflowor and cucumber tho offect in the heated leaf varied with the duration and tomperature of the treatment and that in the opposite unheated leaf varied similarly, though to a lesser extent. As the duration of the heat treatment was extended a bimodal response became apparent in the curvo relating effect to duration, and the dovelopment of endophytic mycelium was further affected by the timo of day at which the treatment was made, by the time of year and by the age of the plant. Thus, in August, 11-day-old cucumber seedlings showed the greatest effect when one cotyledon was heated at $0700 \mathrm{~h}$ following inoculation at $1700 \mathrm{~h}$ the previous day, while in 14-day-old plants this occurred following heating at $1300 \mathrm{~h}$, and the effoct diminished progressively for the succeeding 5 months.

Salmon $^{1}$ found that cross-infection with isolates of $E$. graminis from various cereals and grasses became possible after heat treatment of the hosts; similarly, in the work recorded here, cross-infections with $E$. cichoracearum and $S$. fuliginea were observed. While, however, both isolates produced an endophytic mycelium in sunflower, $E$. cichoracearum from sunflower failed to become endophytic in cucumber. As Yarwood ${ }^{5}$ demonstrated, S. fuliginea from cucumber infected leaves of Phaseolus vulgaris containing heat-killed mycolium of Uromyces phaseoli; further heat treatment of one of a pair of such leaves induced the mycelium of $S$. fuliginea to bocome endophytic, but in the rusted tissues only. This effoct was again translocated to tho unheated leaf.

When crude sap extracts were made from cucumber cotyledons at intervals after heat treatment, and applied to one cotyledon of other plants, which were then inoculated with $S$. fuliginea, an endophytic mycelium was formed, both in the treated and the untreated cotyledons. It is suggested that an active principle predisposing the cucumber cotyledons to this type of infection is formed as a result of the heat treatment and translocated; in bean two substances formed in response to heat and translocated have been demonstrated and to some extent characterized by English et $a l^{8,8}$.

This work was supported by a grant $(G 9820)$ from the U.S. National Science Foundation, and carried out in the laboratory of Dr. C. E. Yarwood, whose advice is gratefully acknowledged.

Department of Plant Pathology, University of California, Berkeley, 4.

* Present address: Scottish Horticultural Research Institute, Invergowrie, Dundee.

'Salmon, E. S., Phil. Trans. Roy. Soc., B, 198, 87 (1906).

${ }^{2}$ Schnathorst, W. C., Phytopathol., 49, 115 (1959).

${ }^{3}$ Yarwood, C. E., Plant Dis. Reptr., 47, 824 (1963).

4 Yarwood, C. E., Plant Dis. Reptr., 48, 310 (1964).

${ }^{5}$ Yarwood, C. E., Phytopathol., 53, 1144 (1963).

${ }^{6}$ Yarwood, C. E., Resonich, E. C., and Kado, C. I., Virology, 16, 414 (1962).

${ }^{7}$ Nienhaus, F., and Yarwood, C. E., Virology, 20, 477 (1963).

${ }^{\prime}$ English, J., and Bonner, J., J. Biol. Chem., 121, 791 (1937).

${ }^{8}$ English, J., Bonner, J., and Haagen-Smit, A. J., Proc. U.S. Nat. Acad. Sci., 25, 323 (1939).

\section{MICROBIOLOGY}

\section{Release of Cores from Bacterial Spores by Mechanical Breakage in Acidic Media}

The dormant bacterial spore consists of a core surrounded by a structure called the cortex which in turn is bounded by a structure called the coat. The core contains eytoplasm plus nuclear material and the cortex contains mucopeptide ${ }^{1}$. The coat is mainly protein $^{2,3}$ with a high cystine disulphide bond content ${ }^{4}$. We have been unable to liberate cores by enzymatic digestion of spore coats using a variety of proteolytic enzymes including keratinase ${ }^{5}$ before or after treatment of spores with reagents which rupture disulphide bonds ${ }^{6}$. We therefore investigated the possibility of releasing cores by mechanical breakage of spores.

Bacterial spores can be broken by shaking spore suspensions with Ballotini beads in the Mickle tissue disintegrator; but no recognizable cores are released by this process. The mechanical resistance of vegetative cells and protoplasts depends on the hydrogen ion concentration $^{7}$ and we therefore examined the effect of $p H$ on the mechanical breakage of spores. The extent of breakage was followed by phase contrast microscopy. When bacterial spores (19 strains of Bacillus and 1 Clostridium strain) were shaken in the Mickle apparatus with Ballotini 